\title{
Effect of Water, Soil Temperatures, and Exposure Times on the Survival of the Sugar Beet Cyst Nematode, Heterodera Schachtii
}

\author{
Trifone D’Addabbo, Nicola Sasanelli, Nicola Greco, Vincenzo Stea, and Antonio Brandonisio
}

Istituto per la Protezione delle Piante, Sezione di Bari, CNR, Via G. Amendola 165/A, 70126 Bari, Italy. Accepted for publication 23 November 2004.

\begin{abstract}
D’Addabbo, T., Sasanelli, N., Greco, N., Stea, V., and Brandonisio, A. 2005. Effect of water, soil temperatures, and exposure times on the survival of the sugar beet cyst nematode, Heterodera schachtii. Phytopathology 95:339-344.

The effect of different combinations of temperatures and exposure times on the mortality of Heterodera schachtii eggs was assessed in two different experiments under laboratory conditions. In the first experiment, cysts in water were exposed to $25,35,37.5,40,42.5,45,47.5,50$, or $52.5^{\circ} \mathrm{C}$ for a maximum period of $2 \mathrm{~h}$. In the second experiment, cysts in

eggs in cysts was assessed by a hatching test in $3 \mathrm{mM}$ zinc chloride solution. Viability in water was suppressed after 2-h exposure at $50^{\circ} \mathrm{C}$ and inhibited after 1 to $2 \mathrm{~h}$ at $52.5^{\circ} \mathrm{C}$. Emergence of juveniles from cysts in soil was greater at the lower temperature $\times$ exposure time combinations and suppressed at higher combinations. Egg mortality started after exposure for $256 \mathrm{~h}$ at $40^{\circ} \mathrm{C}, 32 \mathrm{~h}$ at $42.5^{\circ} \mathrm{C}$, and $16 \mathrm{~h}$ at $45^{\circ} \mathrm{C}$, and 81,31 , and $7 \mathrm{~h}$ of exposure were necessary to kill $50 \%$ of the nematode egg population at $40,42.5$, and $45^{\circ} \mathrm{C}$, respectively. The data fitted the models $P_{t}=$ $P_{0} 10^{-\Delta t /(q+m T)}$ and $P_{T 1}=P_{T 0} 10^{-\Delta T /(z-p t)}$ for $m=-0.0111, q=0.8238, z=$ 2.444 , and $p=-0.23$.
\end{abstract} naturally infested soil were exposed to $25,32.5,35,37.5,40,42.5$, or $45^{\circ} \mathrm{C}$ for a minimum period of $2 \mathrm{~h}$ to a maximum of $2,048 \mathrm{~h}$. Viability of
Additional keywords: Beta vulgaris, nematode mortality, soil solarization.
Characterizing the relationship between mortality of nematode eggs and temperatures requires numerous observations over a wide range of temperatures and exposure times (24). However, sensitivity to temperature stress may vary according to nematode species and life stage. Eggs of the sugar beet cyst nematode Heterodera schachtii Schmidt are tolerant of relatively high temperatures. Triffit and Hurst (30) found that $30 \mathrm{~min}$ of exposure in water at $49^{\circ} \mathrm{C}$ or $10 \mathrm{~min}$ at $60^{\circ} \mathrm{C}$ inhibited juvenile emergence from eggs. Eggs within cysts did not hatch after exposure in water to $60^{\circ} \mathrm{C}$ for $10 \mathrm{~s}$ or to $47.5^{\circ} \mathrm{C}$ for $4 \mathrm{~h}(28)$. Emergence of juveniles was not completely suppressed after $28 \mathrm{~h}$ of exposure to $45^{\circ} \mathrm{C}$. Endo (8) found that the exposure times to inhibit hatch of eggs within cysts of the soybean cyst nematode, $H$. glycines Ichinoe, were $1 \mathrm{~s}, 8 \mathrm{~min}$, and $8 \mathrm{~h}$ at 63,52 , and $44^{\circ} \mathrm{C}$, respectively. With the potato cyst nematode, Globodera rostochiensis Woll., Evans (9) did not observe lethal effect after exposure of cyst to $45^{\circ} \mathrm{C}$ for $7 \mathrm{~h}$, whereas exposure to $50^{\circ} \mathrm{C}$ for $4 \mathrm{~h}$ or to $59^{\circ} \mathrm{C}$ for $0.5 \mathrm{~h}$ killed the eggs.

H. schachtii is an important pest of sugar beet, Beta vulgaris L. var. saccharifera Alefeld, especially in Europe and North America $(2,6)$. The nematode also damages other species of the botanical families Chenopodiaceae and Cruciferae that are used both as field or vegetable crops. In Italy, H. schachtii is widespread (17) and recently has been found associated with severe stunting of cauliflower in Sicily (27). Because cultivars resistant to the nematode are lacking for most crop plants and because of public concern about the use of nematicides, nonchemical control methods are desirable. Among these alternatives, soil solarization is a promising option for control of several soilborne pathogens (21), including nematodes (12). Solarization is effective in Italy $(4,13$, 14,19). Nevertheless, its use would be more efficient with a knowledge-base on time $\times$ temperature responses (26). Therefore,

Corresponding author: T. D’Addabbo; E-mail address: t.daddabbo@ba.ipp.cnr.it

DOI: 10.1094/PHYTO-95-0339

(c) 2005 The American Phytopathological Society the knowledge of the relationship between the survival of the nematode and exposure times at different temperatures is fundamental. Ideally, a mathematical model that accurately describes this relationship, such as the one proposed by Greco et al. (18) for the carrot cyst nematode, $H$. carotae Jones, would be useful for practical application. That model was partly based on graphic calculations. Recently, Sasanelli and Greco (24) suggested another model based exclusively on analytical calculations and, therefore, easier to follow and to fit to the data.

The aim of this investigation was to (i) determine the mortality of $H$. schachtii in relation to exposure to heat and (ii) mathematically characterize the relationship.

\section{MATERIALS AND METHODS}

Two experiments were conducted. In the first experiment, cysts of $H$. schachtii containing eggs were placed in water and exposed to a range of temperatures and times. In the second experiment, naturally infested soil was used to test the effect of a range of temperatures and time exposures on subsequent hatching of the eggs.

The soil used to extract cysts utilized in the first experiment and for incubation in the second experiment was clay-loamy (sand $34 \%$, silt $32.1 \%$, clay $33.5 \%$, and organic matter $2.4 \%$, $\mathrm{pH} 7.6$ ). It was collected in January from a field heavily infested by $H$. schachtii (100 eggs per g of soil) at Avezzano (province of L'Aquila), thoroughly mixed, and kept in the shade outdoors until use.

For the first experiment, cysts were extracted from $200 \mathrm{~cm}^{3}$ of soil with a Fenwick can. The average number per sample was 185 cysts $(25,400$ eggs). Each cohort of the approximately 185 cysts was placed into individual 2-cm-diameter sieves with $215 \mu \mathrm{m}$ apertures and immersed in water heated to $25,35,37.5,40,42.5$, $47.5,50$, and $52.5^{\circ} \mathrm{C}$ for $120 \mathrm{~min}$. Immersion times of 15,30 , and $60 \mathrm{~min}$ were also tested for temperatures $>40^{\circ} \mathrm{C}$ (Table 1). Each temperature $\times$ exposure time treatment was replicated four times. A hatching test was conducted as a means of approximating the 
viability of the eggs. At the end of the exposure times, each sieve was transferred to a $3-\mathrm{cm}$-diameter plastic petri dish (2) containing $3 \mathrm{ml}$ of a $3 \mathrm{mM}$ zinc chloride solution $(5,20)$. These plastic dishes were randomly arranged in $15-\mathrm{cm}$-diameter glass petri dishes and incubated at $25 \pm 2{ }^{\circ} \mathrm{C}$ for 10 weeks. At 7-day intervals, emerged juveniles were counted and the $\mathrm{Zn}$ chloride solution was discarded, and fresh $\mathrm{Zn}$ chloride solution was added to each plastic dish.

At the end of the 10 weeks, the cysts held in each sieve were crushed using Bijloo's modified method (25) to release unhatched eggs. These eggs were counted, and the percent hatched was calculated as the number of hatched juveniles/sum of hatched juveniles + unhatched eggs. Percent unhatched was assumed to represent egg mortality.

In the second experiment, $250-\mathrm{cm}^{3}$ plastic cups were filled with infested soil and water was added to bring the soil moisture content to $33 \mathrm{kPa}$ (43\% of the dry soil weight). Groups of four containers were sealed in plastic bags and placed in growth chambers. The combinations of temperatures $\times$ exposure times that were tested are provided in Table 2 . The tested temperatures were selected based on the results of the first experiment. Each exposure $\times$ temperature combination was replicated four times. At the end of each exposure time, the cysts were extracted from the wet soil with the Fenwick can and incubated at $25 \pm 2{ }^{\circ} \mathrm{C}$ in a $3 \mathrm{mM}$ zinc chloride solution as in the former experiment. The hatching test lasted 10 weeks or until egg hatch became negligible.

Assumed egg mortality data were subjected to probit analysis (10). Also, standard errors were calculated for each treatment. The global standard error from all time $\times$ temperature combinations was calculated using the formula

$$
\mathrm{SD}_{\text {total }}=\mathrm{SQRT}\left[\left(n_{x}-1\right) \mathrm{SD}_{x}^{2}+\left(n_{y}-1\right) \mathrm{SD}_{y}^{2}+\left(n_{z}-1\right) \mathrm{SD}_{z}^{2}+\ldots\right] /\left(N_{\text {total }}-1\right)
$$

TABLE 1. Effect of 15, 30, 60, and 120-min exposure in water at different temperatures on cumulative egg hatch of Heterodera schachtii (\% hatch)

\begin{tabular}{lcccc}
\hline & \multicolumn{4}{c}{ Exposure time (min) } \\
\cline { 2 - 5 } Temperature $\left({ }^{\circ} \mathrm{C}\right)$ & $15^{\mathrm{a}}$ & 30 & 60 & 120 \\
\hline 25 & $\ldots$ & $\ldots$ & $\ldots$ & $70.0 \pm 3.31$ \\
35 & $\ldots$ & $\ldots$ & $\ldots$ & $80.0 \pm 2.44$ \\
37.5 & $\ldots$ & $\ldots$ & $\ldots$ & $61.0 \pm 1.23$ \\
40.0 & $\ldots$ & $\ldots$ & $70.7 \pm 1.14$ & $73.0 \pm 2.54$ \\
42.5 & $\ldots$ & $\ldots$ & $74.0 \pm 1.72$ & $69.2 \pm 1.51$ \\
45.0 & $\ldots$ & $65.5 \pm 1.45$ & $65.5 \pm 2.08$ & $73.7 \pm 1.36$ \\
47.5 & $75.0 \pm 1.91$ & $79.5 \pm 3.04$ & $72.0 \pm 2.62$ & $70.0 \pm 0.76$ \\
50.0 & $67.0 \pm 2.29$ & $69.7 \pm 1.49$ & $71.2 \pm 3.08$ & $57.7 \pm 2.43$ \\
52.5 & $57.7 \pm 3.16$ & $51.5 \pm 2.63$ & $0.3 \pm 0.02$ & $2.5 \pm 0.29$ \\
LSD 0.05 & 8.12 & 7.03 & 8.1 & 10.9 \\
LSD 0.01 & 11.67 & 9.85 & 11.1 & 14.7 \\
\hline
\end{tabular}

a Values are the means of four replicates \pm standard errors. where $x, y$, and $z$ represent the individual time $\times$ temperature treatments, $n$ is the number of replicates in each treatment, and $N$ is the total number of replicates.

To predict the efficacy of a method to control nematodes, information is necessary on the relationship between the rates of the control method and the nematode mortalities that can be achieved. Therefore, to predict the performance of soil solarization in controlling nematodes, a model describing the relationship between nematode survival and exposure times to different temperatures is necessary. Brown and Melling (3) stated that during heat sterilization the $\log$ of microorganisms survival $\times$ exposure time at a constant temperature is a linear relationship. Based on this statement, to calculate the nematode population surviving after a given exposure time to a constant temperature, Sasanelli and Greco (24) proposed the model

$$
P_{t}=P_{0} 10^{-\Delta t /(q+m T)}
$$

In this equation, $P_{t}$ is the nematode population after $\Delta t$ exposure time in hours; $P_{0}$ is the nematode population before the heat treatment; $\Delta t$ is the exposure time above $t_{t}$ (defined as the threshold exposure time $\times$ temperature below which the nematode is not killed); $m$ and $q$ are the angular coefficient and the known term ( $y$-axis intercept), respectively, of the straight line that represents the function $\alpha=f(T)$; and $T$ is the temperature in degrees Celsius to which the nematode population is exposed. The value of $\alpha$ corresponds to the nematode decimal reduction time, i.e., the exposure time, above the threshold time at a given constant temperature, required to reduce the initial nematode population $\left(P_{0}\right)$ to $1 / 10$. It is assumed that $\alpha$ is constant for each nematode species and temperature; therefore $\alpha=f(T)$.

To calculate values of $\alpha$, for each of the temperatures that reduced egg hatch, log of percent nematode survival observed at exposure times $>$ threshold exposure time (defined as the exposure times to a given temperature up to which no hatch reduction occurred) were plotted against exposure times at the given temperature, and a straight line was fitted according to Sasanelli and Greco (24).

Values of $\alpha$ were then plotted against temperature to derive the equation representing $\alpha=f(T)$. In this equation, the slope and the $y$ intercept correspond to $m$ and $q$ in equation 1 .

A similar model was proposed to estimate the nematode population after a constant exposure time to varying temperatures (24). In this case, the model is

$$
P_{T 1}=P_{T 0} 10^{-\Delta T /(z-p t)}
$$

where $P_{T 1}$ and $P_{T 0}$ are the nematode populations (at the same exposure time) at $T_{1}$ and $T_{0} ; \Delta T$ is the temperature increase $\left(T_{1}-\right.$ $\left.T_{0}\right) ; p$ and $z$ are the angular coefficient and the known term ( $y$ intercept), respectively, of the straight line that represents the function $\beta=f(t)$ or $\beta=f(\log t)$; and $t$ is time of nematode population exposure to temperature $T_{1}$. The value of $\beta$ corresponds to

\begin{tabular}{|c|c|c|c|c|c|c|c|}
\hline \multirow[b]{2}{*}{ Exposure (hours) } & \multicolumn{7}{|c|}{ Temperatures $\left({ }^{\circ} \mathrm{C}\right)$} \\
\hline & $25^{\mathrm{a}}$ & 32.5 & 35 & 37.5 & 40 & 42.5 & 45 \\
\hline 2 & $53.7 \pm 2.35$ & $\ldots$ & $\ldots$ & $\ldots$ & $\ldots$ & $\ldots$ & $\ldots$ \\
\hline 4 & $58.3 \pm 2.21$ & $\ldots$ & $\ldots$ & $\ldots$ & $\ldots$ & $\ldots$ & $\ldots$ \\
\hline 16 & $75.8 \pm 3.18$ & $\ldots$ & $\ldots$ & $\ldots$ & $\ldots$ & $\ldots$ & $8.9 \pm 0.66$ \\
\hline 32 & $76.3 \pm 2.71$ & $\ldots$ & $\ldots$ & $\ldots$ & $82.1 \pm 3.15$ & $47.1 \pm 3.21$ & $0.3 \pm 0.06$ \\
\hline 64 & $60.8 \pm 2.59$ & $\ldots$ & $\ldots$ & $\ldots$ & $48.8 \pm 1.52$ & $0.6 \pm 0.09$ & $0.2 \pm 0.05$ \\
\hline 1,024 & $76.1 \pm 1.62$ & $69.5 \pm 0.75$ & $75.6 \pm 1.51$ & $75.4 \pm 3.11$ & $0.0 \pm 0.00$ & $0.0 \pm 0.00$ & $0.0 \pm 0.00$ \\
\hline 2,048 & $83.5 \pm 1.79$ & $88.1 \pm 1.08$ & $86.9 \pm 2.36$ & $61.5 \pm 1.61$ & $0.0 \pm 0.00$ & $0.0 \pm 0.00$ & $0.0 \pm 0.00$ \\
\hline
\end{tabular}
nematode decimal reduction temperature, the temperature in-

TABLE 2. Percent cumulative hatch of Heterodera schachtii after soil exposure at different time $\times$ temperature combinations

a Values are the means of four replicates \pm standard errors. 
crease (at the same exposure time) required to reduce the nematode population occurring at $T_{0}$ to $1 / 10$. Also, $\beta$ can be calculated as the inverse of the angular coefficient of the straight line characterizing the function $\log _{10} P=f(T)$. Its value is assumed to be the same for each nematode species and exposure time. Values of $\beta$ were determined by plotting log nematode survivals against given temperatures at each exposure time, as they correspond to the inverse of the slopes of the straight lines $(\beta=-1 / b)$. Values of $\beta$ were then plotted against log exposure times to derive the equation of the straight line representing $\beta=f(t)$. In this equation, the slope and the $y$ intercept are $p$ and $z$ in equation 2 .

Therefore, to characterize the relationship between survival of $H$. schachtii eggs as affected by a range of temperatures and exposure times, the logs of egg survival observed in the second experiment were used to calculate $q$ and $m$ and $p$ and $z$ in equation 1 and equation 2 , respectively.

\section{RESULTS}

The standard error was rather low for all data, indicating little variability among replicates. Values of global standard error were 1.85 and 1.57 for the experiment in water and in soil, respectively.

Exposure of cysts for 1 to $2 \mathrm{~h}$ in water at $52.5^{\circ} \mathrm{C}$ completely inhibited egg hatch but no hatch reduction was observed after exposure for 15 or $30 \mathrm{~min}$. After $2 \mathrm{~h}$ at $50^{\circ} \mathrm{C}$, emergence of juveniles was delayed during the first 4 weeks but reached $58 \%$ by the end of the hatching test. Cysts were not affected by $2 \mathrm{~h}$ in water at 25 to $47.5^{\circ} \mathrm{C}$ and had similar final hatch percents and hatching patterns (Table 1). Most of the juveniles emerged during the first 5 weeks and only a few thereafter. Total cumulative hatch was 70 to $80 \%$.

In the second experiment, cysts at $25^{\circ} \mathrm{C}$, considered the reference temperature, had rather low final hatch percent (53.7 to $58.3 \%$ ) when exposed for 2 to $4 \mathrm{~h}$ and much higher juvenile emergence $(83.5 \%)$ at the longest exposure times $(2,048 \mathrm{~h}$ ) (Table 2 ). The suppressive effect of the heat started clearly at $40^{\circ} \mathrm{C}$. At this temperature, egg hatch was not reduced after a 32-h exposure, but after 64 to $128 \mathrm{~h}$, emergence of juveniles was delayed by 1 week and reached only 40 to $49 \%$ by the end of the incubation period. Longer exposure at this temperature resulted in complete inhibition of egg hatch. At $42.5^{\circ} \mathrm{C}$, hatch was again delayed by 1 week after $32-\mathrm{h}$ exposure and was $47 \%$ at the end of the test; there was no hatch when exposure lasted $\geq 64 \mathrm{~h}$. At $45^{\circ} \mathrm{C}$, total emergence was $48 \%$ after 8-h exposure, negligible (9\%) after $16 \mathrm{~h}$, and completely inhibited at longer exposure times. No reduction of egg hatch occurred at $37.5^{\circ} \mathrm{C}$ up to 1,024-h exposure and only a little at 2,048-h exposure.

At 32.5 and $35^{\circ} \mathrm{C}$, maximum egg hatch was obtained at $2,048 \mathrm{~h}$ ( 87 to $88 \%$ ), but total hatch percent was always above $70 \%$ at all shorter exposure times. Most of the juveniles emerged during the first 4 weeks ( 82 to $85 \%$ ) and much fewer during the remaining 6 weeks.

Probit analysis was conducted only on data for temperatures $\geq 40^{\circ} \mathrm{C}$ because no egg mortality occurred at lower temperatures. The correlation coefficients $(r)$ of the linear regression equation relating percentage of emerged juveniles to exposure times were highly significant for all three temperatures $\left(40,42.5\right.$, and $\left.45^{\circ} \mathrm{C}\right)$ (Fig. 1). Exposure times required to attain a $50 \%$ mortality were $81 \mathrm{~h}$ at $40^{\circ} \mathrm{C}, 31 \mathrm{~h}$ at $42.5^{\circ} \mathrm{C}$, and $7 \mathrm{~h}$ at $45^{\circ} \mathrm{C}$, and a $90 \%$ mortality could be reached after 170-, 44-, and 14-h exposure at $40,42.5$, and $45^{\circ} \mathrm{C}$, respectively.

Plotting log egg hatch of each suppressive temperature against $\log$ of exposure times causing reduction of egg hatch (64 to $1,024 \mathrm{~h}$ at $40^{\circ} \mathrm{C} ; 32$ to $512 \mathrm{~h}$ at $42.5^{\circ} \mathrm{C}$; and 8 to $128 \mathrm{~h}$ at $45^{\circ} \mathrm{C}$ ) gave equations of the straight lines representing this relationship at these temperatures. These equations (Fig. 2) enabled the calculation of $\alpha$ values that were 0.3993 at $40^{\circ} \mathrm{C}, 0.318$ at $42.5^{\circ} \mathrm{C}$, and 0.344 at $45^{\circ} \mathrm{C}$. It must be noted that these values are all derived from regression straight lines with a highly significant regression coefficient. The $\alpha$ values were plotted against temperature (Fig. 3 ), and values of $m$ and $q$ of -0.011 and 0.8238 , respectively, were derived from the straight line representing this relationship. Therefore, equation 1 for $H$. schachtii is

$$
P_{t}=P_{0} 10^{-\Delta t /(0.8238-0.011 T)}
$$

Similarly, values calculated for $\beta$ were 2.079 at $32 \mathrm{~h}, 2.069$ at $64 \mathrm{~h}, 1.920$ at $128 \mathrm{~h}, 1.809$ at $256 \mathrm{~h}$, and 1.853 at $512 \mathrm{~h}$ (Fig. 4). These values were then plotted against log exposure time (Fig. 5) to derive the equation representing $\beta=f(\log t)$, in which the slope $(-0.236)$ and the $y$ intercept (2.444) correspond to $p$ and $z$ in equation 2 , which becomes

$$
P_{T 1}=P_{T 0} 10^{-\Delta T /(2.444+0.236 t)}
$$

Exposure times predicted by the model for different levels of mortality are lower than values deriving from probit analysis at $40^{\circ} \mathrm{C}$, but the result is always higher at 42.5 and $45^{\circ} \mathrm{C}$ (Table 3). However, differences were not statistically significant according to Student's $t$ test. The correlation between estimated exposure times and mortality levels yielded an $R^{2}$ of approximately 0.90 at all temperatures in the proposed model versus 0.95 to 0.98 in probit analysis.
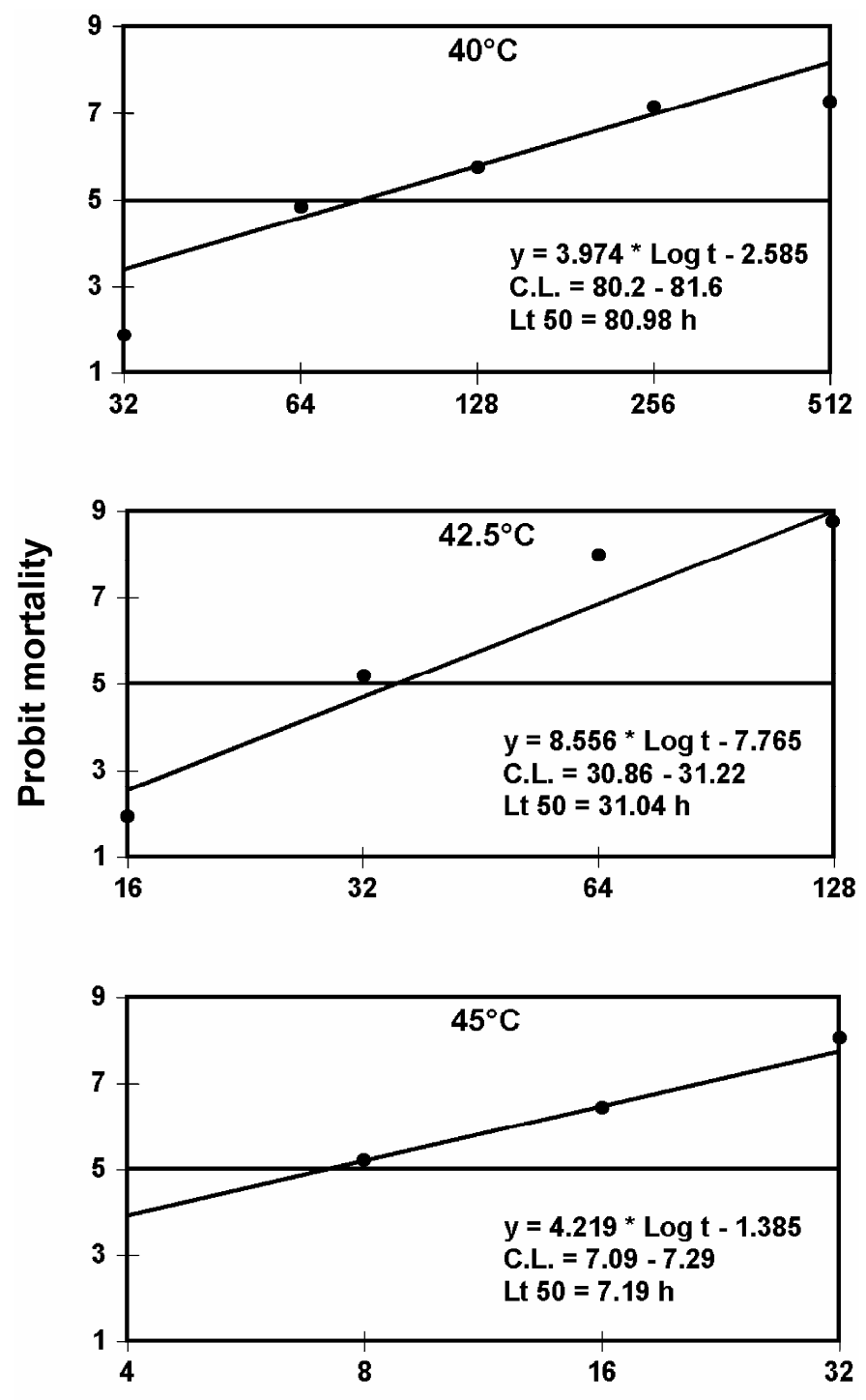

Exposure time (hours)

Fig. 1. Relation between exposure time and probit mortality of eggs of Heterodera schachtii in soil at $40,42.5$, and $45^{\circ} \mathrm{C}$ (C.L. $=$ confidence limit). 


\section{DISCUSSION}

Eggs of cyst nematodes may undergo a dormancy or diapause period during which egg hatch is nil or poor. This is well known for the cereal cyst nematode, $H$. avenae Woll. (11) and potato cyst
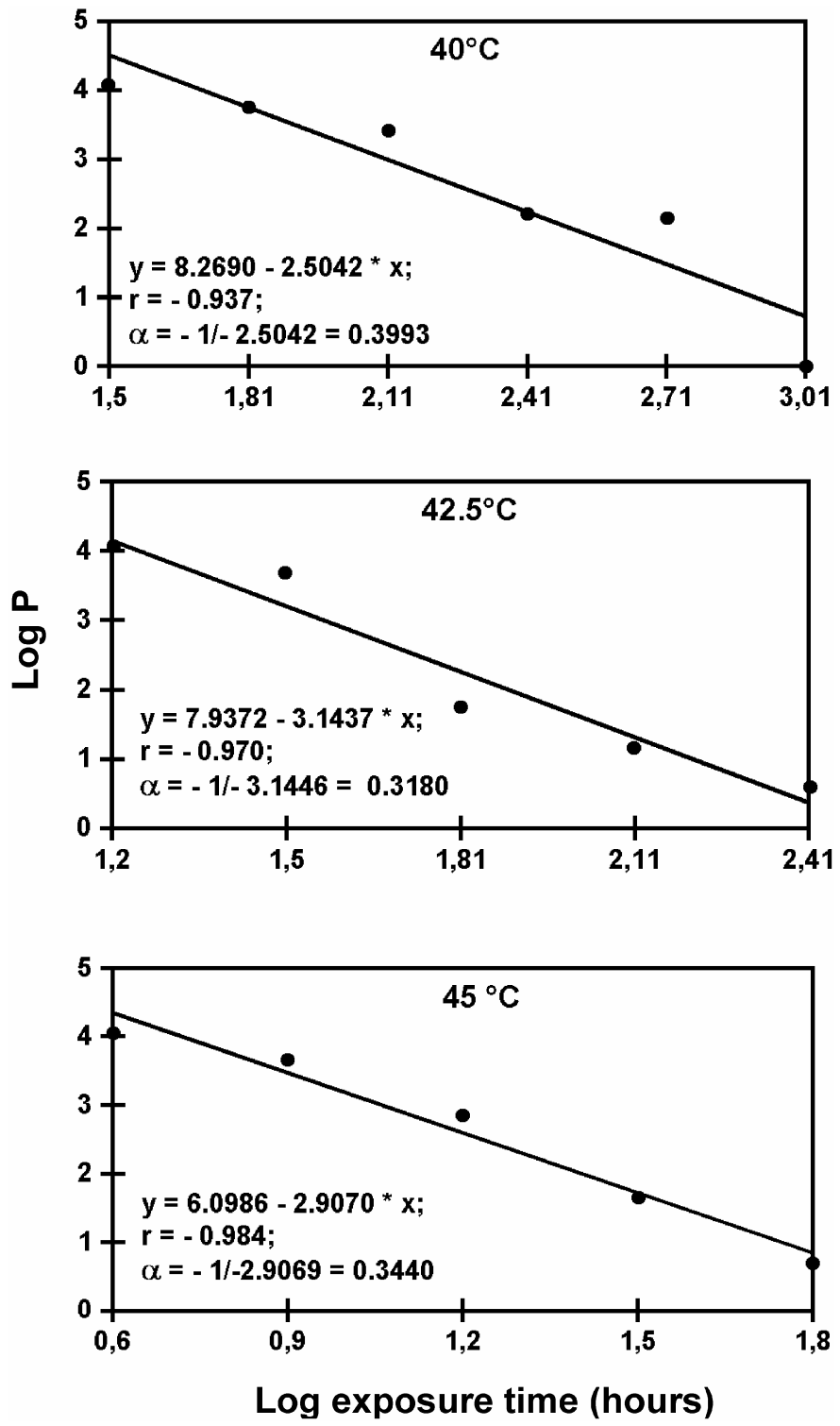

Fig. 2. Regression straight lines describing the relationship between log nematode population and $\log$ exposure time at $40,42.5$, and $45^{\circ} \mathrm{C}$ for calculation of $\alpha$ values (nematode decimal reduction time).

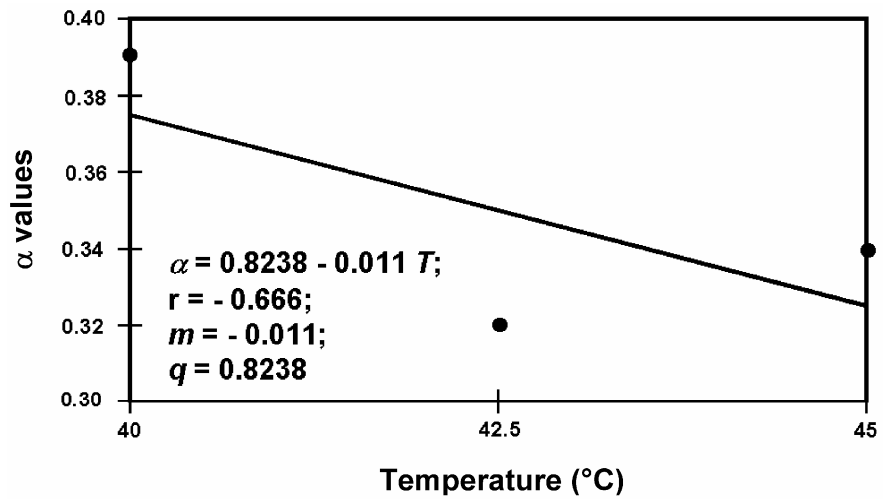

Fig. 3. Relationship between temperature and values of $\alpha$ and calculation of the parameters $q$ and $m$ in equation 1 . nematode $G$. rostochiensis (23), under temperate climatic conditions. Therefore, one may question whether the lack of or poor hatch of eggs exposed to rather high temperature is due to lethal effect or to induction of dormancy. Greco et al. (15) did not observe a clear dormancy of $H$. schachtii eggs from the same area although Zheng and Ferris (32) reported significant differences in hatch of eggs of this nematodes produced or stored under different environmental conditions. From Table 2 it is evident that the exposure to temperature caused an increase in percent egg
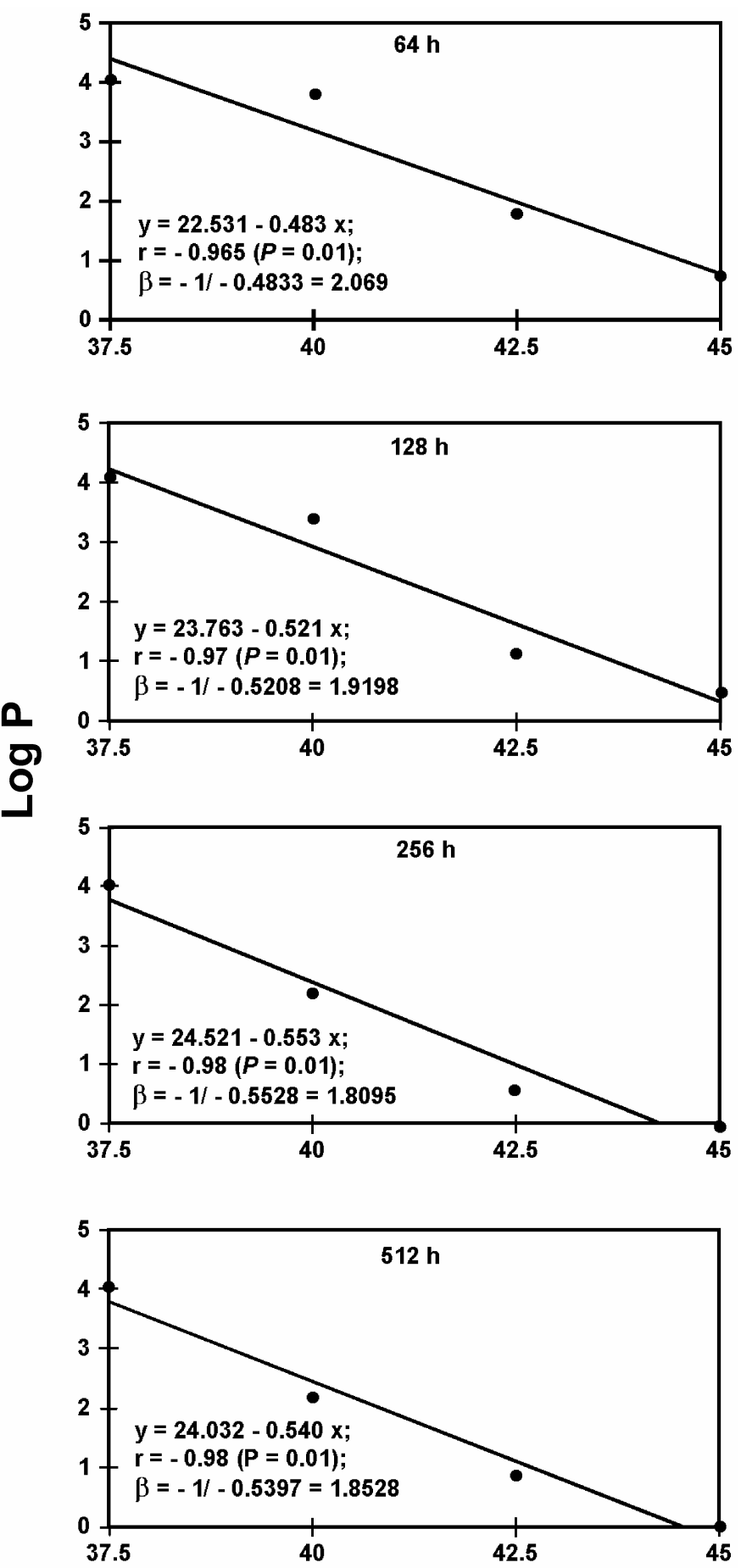

\section{Temperature $\left({ }^{\circ} \mathrm{C}\right)$}

Fig. 4. Regression straight lines describing the relationship between log nematode population and temperatures at 32,64, 128, 256, and $512 \mathrm{~h}$ for calculation of $\beta$ values (nematode decimal reduction temperature). 
hatch at low temperature $\times$ exposure time combinations and a sharp reduction at higher combinations. This would exclude an induction of dormancy due to temperature effect in our experiments. Nevertheless, the infested soil was collected from the field at the end of January, when cysts were at least 3 to 4 months old, and the hatching tests were conducted for a period long enough to interrupt dormancy (a minimum of 10 weeks in the second experiment). Therefore, it is reasonable to assume that nonhatched eggs were dead due to the lethal effect of exposure to temperature. The fact that $100 \%$ egg hatch was not attained even at low temperature $\times$ exposure combination can be attributed to the presence of nonviable eggs and/or eggs infected by fungi, $12 \%$ in Greco et al. (15). Moreover, to avoid loss of hatch stimulation with aging, we used a solution of an inorganic compound $(3 \mathrm{mM}$ zinc chloride) as hatching agent, instead of host plant root diffusate. This compound is more stable and known to induce hatching similar to that of sugar beet root diffusate.

According to the results of the first experiment, a 2-h exposure of cysts in water up to $47.5^{\circ} \mathrm{C}$ did not affect hatchability. At $50^{\circ} \mathrm{C}$ juvenile emergence was only delayed and partially suppressed. Temperatures above $50^{\circ} \mathrm{C}$ were lethal (caused at least $80 \%$ egg mortality) only if exposure was for at least $2 \mathrm{~h}$.

The experiment with infested soil demonstrated the increasing effects of different short heat treatments on hatchability of $H$. schachtii, as previously observed for $H$. carotae (18). An increasing effect was found at low temperature and exposure time combinations and a decreasing effect at higher combinations. The decreasing effect is the only one of practical interest. For H. schachtii, at least $64-\mathrm{h}$ exposure at $40^{\circ} \mathrm{C}$ is required to achieve a satisfactory level of control. These findings are similar to those of Steele (28). This temperature can be achieved in solarized soil at depths of up to $10 \mathrm{~cm}$ in many areas. However, in southern Italy, temperatures ranging from 38 to $40^{\circ} \mathrm{C}$ have also been recorded at $30 \mathrm{~cm}$ deep in solarized soil. The potential for control of $H$. schachtii by soil solarization is good in these areas.

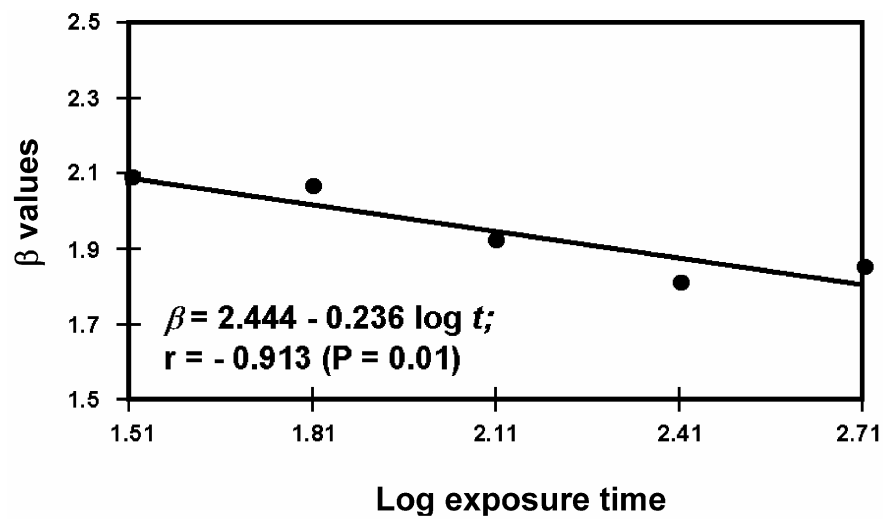

Fig. 5. Relationship between $\log$ exposure time and values of $\beta$ and calculation of the parameters $z$ and $p$ in equation 2 .

TABLE 3. Comparison of exposure times estimated by probit analysis and the proposed model to achieve different levels of mortality of eggs of Heterodera schachtii at $40,42.5$, and $45^{\circ} \mathrm{C}$

\begin{tabular}{|c|c|c|c|c|c|c|}
\hline \multirow[b]{3}{*}{ Mortality (\%) } & \multicolumn{6}{|c|}{ Exposure time (h) } \\
\hline & \multicolumn{2}{|c|}{$40^{\circ} \mathrm{C}$} & \multicolumn{2}{|c|}{$42.5^{\circ} \mathrm{C}$} & \multicolumn{2}{|c|}{$45^{\circ} \mathrm{C}$} \\
\hline & Probit & Model & Probit & Model & Probit & Model \\
\hline 50 & 81.0 & 84.4 & 31.0 & 40.9 & 7.2 & 10.0 \\
\hline 60 & 92.5 & 91.0 & 33.6 & 44.3 & 9.0 & 10.8 \\
\hline 70 & 108.1 & 101.6 & 36.3 & 49.1 & 10.1 & 11.9 \\
\hline 80 & 129.7 & 118.7 & 39.9 & 56.8 & 11.4 & 13.6 \\
\hline 90 & 167.0 & 154.9 & 45.3 & 72.7 & 13.7 & 17.0 \\
\hline$R^{2}$ & 0.946 & 0.898 & 0.973 & 0.905 & 0.984 & 0.915 \\
\hline
\end{tabular}

The model is satisfactory for temperatures $\geq 40$, but less so at lower temperatures and can be used to derive the duration of the exposure to soil temperatures necessary to reduce a given population of $H$. schachtii to a desired level. In our case, reducing the initial population density of 100 eggs per $g$ of soil to 1.8 eggs per $\mathrm{g}$ of soil, corresponding to the tolerance limit of sugar beet for $H$. schachtii in Italy (16), would require an exposure to $45^{\circ} \mathrm{C}$ for $29 \mathrm{~h}, 42.5^{\circ} \mathrm{C}$ for $65 \mathrm{~h}$, or $40^{\circ} \mathrm{C}$ for $147 \mathrm{~h}$. The exposure would be reduced to $7 \mathrm{~h}$ at $47.5^{\circ} \mathrm{C}$ and to about $3 \mathrm{~h}$ at $50^{\circ} \mathrm{C}$. Such temperatures can be reached in the top $10 \mathrm{~cm}$ of solarized soil $(1,7)$.

Several models are available to predict soil temperature in the soil profile under different mulches, including plastic films, which are based on available meteorological data and soil and mulch properties $(22,29,31)$. These models are useful to predict soil temperature under different climatic and soil conditions and thus estimate the effectiveness of soil solarization using our model. Prior to solarization, the soil is ploughed to a depth of about $30 \mathrm{~cm}$. Therefore, because cysts are not motile, the population of cyst nematodes is more uniform throughout the top $30 \mathrm{~cm}$ of the soil profile.

Comparing these results with those of previous studies suggests that $H$. schachtii is much more sensitive than $H$. carotae to heat stress (18). For instance, to reduce nematode population to $1.5 \%$ of the initial density, an exposure of $24 \mathrm{~h}$ at $45^{\circ} \mathrm{C}$ is required for $H$. schachtii, but $60 \mathrm{~h}$ is required for $H$. carotae. At the same temperature, a reduction of nematode population to $3 \%$ would require 19-h exposure for $H$. schachtii and $52 \mathrm{~h}$ for $H$. carotae. Differences in metabolism and ecological amplitude may account for the different sensitivity of the two nematode species. The difference observed in the survival ability of these two cyst nematode species, to the same range of temperatures $\times$ exposure times, suggests that parameters cannot be used interchangeably among nematode species. Parameter values must be determined experimentally for each species.

Finally, the models described here could also fit survival data of other soilborne microorganisms in relation to exposures to a range of temperatures.

\section{LITERATURE CITED}

1. Arcidiacono, C., Cascone, G., Fichera, C. R., and Gutkowski, D. 1997. Thermal effects of coextruded black mulches in greenhouse soil solarization. Pages 110-120 in: Soil Solarization and Integrated Management of Soilborne Pests. J. J. Stapleton, J. E. DeVay, and C. L. Elmore, eds. FAO Plant Prod. Prot. Pap. 147.

2. Baldwin, J. G., and Mundo-Ocampo, M. 1991. Heteroderinae, cyst- and non-cyst-forming nematodes. Pages 275-362 in: Manual of Agricultural Nematology. W. R. Nickle, ed. Marcel Dekker, New York.

3. Brown, M. R. V., and Melling, J. 1971. Inhibition and destruction of microorganisms by heat. Pages 1-37 in: Inhibition and Destruction of Microbial Cell. N. P. Hugo, ed. Academic Press, New York.

4. Cartia, G., Greco, N., and Di Primo, P. 1998. Experience acquired in southern Italy in controlling soilborne pathogens by soil solarization and chemicals. Pages 351-366 in: Soil Solarization and Integrated Management of Soilborne Pests. J. J. Stapleton, J. E. DeVay, and C. L. Elmore, eds. FAO Plant Prod. Prot. Pap. 147. FAO.

5. Clarke, A. J., and Shepherd, A. M. 1966. Inorganic ions and the hatching of Heterodera spp. Ann. Appl. Biol. 58:497-508.

6. Cooke, D. 1993. Nematode parasites of sugarbeet. Pages 133-169 in: Plant-Parasitic Nematodes in Temperate Agriculture. K. Evans, D. L. Trudgill, and J. M. Webster, eds. CAB International, Wallingford, UK.

7. DeVay, J. E. 1990. Historical review and principles of soil solarization. Pages 1-15 in: Soil Solarization and Integrated Management of Soilborne Pests. J. J. Stapleton, J. E. DeVay, and C. L. Elmore, eds. FAO Plant Prod. Prot. Pap. 109.

8. Endo, B. J. 1962. Lethal time-temperature relations for Heterodera glycines. Phytopathology 52:992-997.

9. Evans, K. 1991. Lethal temperatures for eggs of Globodera rostochiensis determined by staining with New Blue R. Nematologica 37:225-229.

10. Finney, D. J. 1971. Probit Analysis. A Statistical Treatment of the Sigmoid Response Curve. 3rd ed. Cambridge University Press, Cambridge.

11. Fushtey, S. G., and Johnson, P. W. 1966. The biology of the oat cyst nematode, Heterodera avenae, in Canada. I. The effect of temperature on 
the hatchability of cysts and emergence of larvae. Nematologica 12:313320 .

12. Gaur, H. S., and Perry, R. N. 1991. The use of soil solarization for control of plant parasitic nematodes. Nematol. Abstr. 60:153-167.

13. Greco, N., Brandonisio, A., and Dangelico, A. 2000. Control of the potato cyst nematode, Globodera rostochiensis, with soil solarization and nematicides. Nematol. Mediterr. 28:93-99.

14. Greco, N., Brandonisio, A., and Elia, F. 1985. Control of Ditylenchus dipsaci, Heterodera carotae and Meloidogyne javanica by solarization. Nematol. Mediterr. 13:191-197.

15. Greco, N., Brandonisio, A., and De Marinis, G. 1982. Investigation on the biology of Heterodera schachtii in Italy. Nematol. Mediterr. 10:201-214.

16. Greco, N., Brandonisio, A., and De Marinis, G. 1982. Tolerance limit of the sugarbeet to Heterodera schachtii. J. Nematol. 14:199-202.

17. Greco, N., D'Addabbo, T., Brandonisio, A., and Elia, F. 1993. Damage to Italian crops caused by cyst-forming nematodes. J. Nematol. 25(S):836842.

18. Greco, N., D’Addabbo, T., Sasanelli, N., Seinhorst, J. W., Stea, V., and Brandonisio, A. 1998. Effect of temperature and exposure times on the mortality of the carrot cyst nematode Heterodera carotae. Int. J. Pest Manag. 44:99-107.

19. Greco, N., D'Addabbo, T., Stea, V., and Brandonisio, A. 1992. The synergism of soil solarization with fumigant nematicides and straw for the control of Heterodera carotae and Ditylenchus dipsaci. Nematol. Mediterr. 20:25-32.

20. Greet, D. N. 1974. The response of five round cyst nematodes (Heteroderidae) to five artificial hatching agents. Nematologica 20:363-364.

21. Katan, J., and Devay, J. E. 1991. Soil Solarization. CRC Press, Boca Raton, FL.

22. Mahrer, Y. 1979. Prediction of soil temperature of a soil mulched with transparent polyethylene. J. Appl. Meteorol. 18:1263-1267.

23. Perry, R. N. 1998. The physiology and sensory of potato cyst nematode, Globodera species. Pages 27-49 in: Potato Cyst Nematodes: Biology, Distribution and Control. R. J. Marks and B. B. Brodie, eds. CAB International, Wallingford, UK.

24. Sasanelli, N., and Greco, N. 2000. Formulation of a model to relate nematode populations with exposure times to a range of temperatures. Acta Hortic. 532:131-135.

25. Seinhorst, J. W., and den Ouden, H. 1966. An improvement of Bijloo's method for determining the egg content of Heterodera cysts. Nematologica 12:170-171.

26. Shlevin, E., Saguy, I. S., Mahrer, Y., and Katan, J. 2003. Modeling the survival of two soilborne pathogens under dry structural solarization. Phytopathology 93:1247-1257.

27. Spatafora, F., Sasanelli, N., Vovlas, N., and Federico, R. 2004. Contemporanea presenza di due specie di nematodi endoparassiti in coltivazioni deperienti di cavolfiore in Sicilia. Pages 231-234 in: Proc. Giornate Fitopatologiche. Pescara, Italy.

28. Steele, A. E. 1973. The effect of hot water treatments on survival of Heterodera schachtii. J. Nematol. 5:81-84.

29. Sui, H., Zeng, D., and Chen, F. 1992. A numerical model for simulating the temperature and moisture regimes of soil under various mulches. Agric. For. Meteorol. 61:281-299.

30. Triffit, M. J., and Hurst, R. H. 1935. On the thermal death point of Heterodera schachtii. J. Helminthol. 13:219-222.

31. Wu, Y., Perry, K. B., and Ristaino, J. B. 1996. Estimating temperature of mulched and bare soil from meteorological data. Agric. For. Meteorol. 81:299-323.

32. Zheng, L., and Ferris, H. 1991. Four types of dormancy exhibited by eggs of Heterodera schachtii. Rev. Nématol. 14:419-426. 